\title{
WATER VAPOUR TRANSPORT FROM THE TROPICAL ATLANTIC AND SUMMER RAINFALL IN TROPICAL SOUTHERN AFRICA
}

\author{
Nicolas Vigaud*, Y. Richard ${ }^{* *}$, M. Rouaultt, N. Fauchereau ${ }^{* *}$ \\ Departement of Oceanography, University of Cape Town, South Africa
}

\section{INTRODUCTION}

Within tropical areas of Southern and Central Africa, rainfall regimes are largely dependent on deep convection processes and water vapour convergence at different tropospheric levels. The main source of variability in tropical African climate is linked to the latitudinal position of the Intertropical Convergence Zone (ITCZ) (PrestonWhyte and Tyson, 1988; Schott et al., 2003), a highly energetic feature of Earth climate, migrating to its southernmost position in May over Brazil and in February over southeast Africa. Except for the Congo basin and eastern Tanzania, most regions of tropical southern Africa have one dry and one rainy season. Maximum in rainfall tend to occur from November to April. Different mechanisms are known to characterize early and late summer rainfall (D'Abreton and Tyson, 1995; Nicholson, 2000). D'Abreton and Lyndesay (1993) report changes in zonal and meridional transport of water vapour over southern Africa during wet and dry summers, with the neighboring oceans contributing as moisture sources. The tropical Atlantic is still regarded as a secondary source of moisture over the subcontinent (Preston-Whyte and Tyson, 1988; D'Abreton and Lindesay, 1993). However a positive correlation has been established between SST anomalies off Angola and rainfall at the coast (Hastenrath and Hirst, 1983; Nicholson and Entekhabi, 1987; Camberlin and Poccard, 2001; Rouault et al., 2003). In the following, we try to investigate the role of the tropical Atlantic in moisture input over southern tropical Africa, and the potential impacts on local rainfall regimes.

\section{DATA \& METHOD}

Despite the fact that tropical southern Africa is one of the most energetic place in the world in terms of convection processes, it is still one of the least studied areas regarding moisture exchanges. We computed moisture fluxes from the newly released 6 hourly NCEP-DOE AMIP Re-analyses dataset (Kanamitsu et al., 2002) over the 1979-2003

\footnotetext{
* Dept of Oceanography, Univ. Cape Town, Private bag, Rondebosh 7701, South Africa; e-mail: nvigaud@ocean.uct.ac.za.

** Centre de Recherches de Climatologie, UMR 5210, CNRS / Univ. Bourgogne, Dijon, France.
}

period, at 8 pressure levels between $1000 \mathrm{mb}$ and $300 \mathrm{mb}$ over an area ranging from $2.5^{\circ} \mathrm{N}$ to $37.5^{\circ} \mathrm{S}$ in latitude and from $5^{\circ} \mathrm{E}$ to $50^{\circ} \mathrm{E}$ in longitude. At a given level, the horizontal moisture flux can be defined as follow,

$$
Q_{l v l}=q_{l v l} \cdot v_{l v l}
$$

where $q_{l v l}$ and $v_{l v l}$ are the specific humidity and horizontal velocities at the given tropospheric level. For each level, moisture convergence was calculated from the divergence of zonal and meridional moisture fluxes. At monthly or seasonally time scales, the variations of precipitable water in a given volume can be approximated as following (Peixoto and Oort, 1992),

$$
-\operatorname{div} Q=P-E
$$

An excess in precipitation $(P)$ over evaporation $(E)$ locally corresponds to a convergence of humidity fluxes while the reverse leads to humidity divergence.

Furthermore, it is possible to decompose the humidity ux in its stationary and transient component,

$$
Q^{\text {tot }}=Q^{\text {stat }}+Q^{\text {trans }}
$$

When averaging over a long enough time scale,

$$
Q^{t o t}=q^{*} \cdot v^{*}+q^{\prime} \cdot v^{\prime}
$$

where, $\left(q^{*} ; v^{*}\right)$ and $\left(q^{\prime} ; v^{\prime}\right)$ respectively represent stationary and transient specfic humidity and wind. The first term witnesses of the mean moisture flux through the mean circulation while the second term is the contribution of fluctuations from the mean.

Simultaneously, we used rainfall estimates from the Climatic Research Unit, CRU TS 2.0 dataset (Mitchell et al., 2004) offering monthly values from 1901 to 2000 at a $0.5^{\circ} \times 0.5^{\circ}$ spatial resolution.

Finally, we also processed NCEP R2 vertical velocities at 2.5 degrees spatial resolution over the 1979-2003 period. 


\section{MOISTURE CONVERGENCE IN TROPICAL SOUTHERN AFRICA \& CONTRIBUTION FROM THE TROPICAL ATLANTIC}

\subsection{Climatological Overview}

January-February vector moisture fluxes maps with contours of mean humidity convergence at 850, 700 and $500 \mathrm{mb}$ are shown in Figure 1.
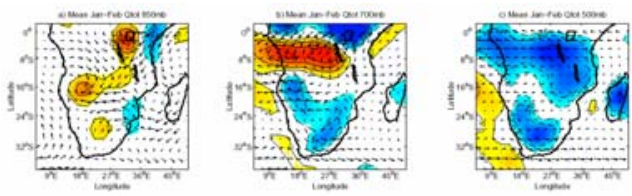

Figure 1 : Mean January-February surface moisture fluxes (streamlines in $g . \mathrm{kg}^{-1} \cdot \mathrm{m} . \mathrm{s}^{-1}$ with arrows scaled at 1 unit/degree of latitude) together with contours of moisture convergence (in $\mathrm{g} \cdot \mathrm{kg}^{-1} \cdot \mathrm{s}^{-1}$ ) at $850 \mathrm{mb}(\mathrm{a}), 700 \mathrm{mb}$ (b) and $500 \mathrm{mb}$ (c). Positive values contour areas of moisture convergence while negative values refer to moisture divergence at given levels.

Pronounced moisture convergence at surface (850 mb) appear to match with marked divergence in mid-tropospheric levels (700 to $500 \mathrm{mb}$ ) and help identify three major convective areas in summer over the subcontinent. Deep convection processes are found to take place to the East of the Congo basin (around $30^{\circ} \mathrm{E}$ ). In southeastern Angola, centered at about $17^{\circ} \mathrm{S}$ over the Bie plateau, is a local feature known as the Angola low (Mulenga, 1998; Cook et al., 2004; Reason and Jagadheesha, 2005). Stronger divergence at 700 $\mathrm{mb}$ over south Angola suggests substantial convection mechanisms there, but less deep within the air column. Further south, a third lowlevel convergence zone is found to the south of Botswana at about $25^{\circ} \mathrm{E}$ corresponding with the subtropical heat low location in summer.

To quantify zonally the exchange in moisture at the land-ocean interface and thus, the role of the Atlantic in modulating southern African climate, we used a vertical domain along the west coast of southern Africa for zonal moisture fluxes. The mean January-February climatological structure is presented in Figure 2.
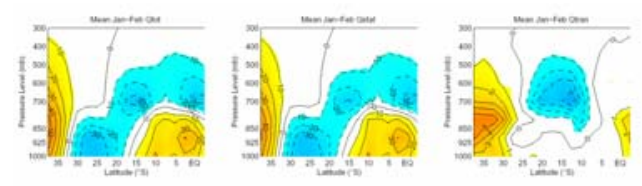

Figure 2 : Mean vertical structure of zonal moisture fluxes along the west coast of southern for JanuaryFebruary Africa (in $g \cdot \mathrm{kg}^{-1} \cdot \mathrm{m} \cdot \mathrm{s}^{-1}$ ) together with its stationary and transient components. Positive/negative values correspond to westerly/easterly fluxes.
In the tropics, the transient term represents less than $10 \%$ of the total zonal moisture transport. This agrees with previous studies (Chen, 1985, Rocha and Simmonds, 1997; Fauchereau, 2004) stating that the steady component in water vapour fluxes is well suited to represent moisture changes due to large-scale circulation in the tropics. Finally four key features are highlighted throughout the year :

(a) a westerly monsoon-like flux from the equator to $15^{\circ} \mathrm{S}$ at surface levels in summer. When particularly pronounced this flux appears to feed in deep convection to the east of the Congo basin,

(b) overlying this westerly flux, the southern extension of the African Easterly Jet (AEJ) at midtropospheric levels as described in Hastenrath (1985), migrating in both latitudes and heights with the seasonal cycle. It is found just above $700 \mathrm{mb}$ in January-February, while it is located at lower levels from March to August (not shown), when it is at about $4^{\circ} \mathrm{S}$, agreeing with the description given in Nicholson and Grist (2003),

(c) to the south (between $17^{\circ} \mathrm{S}$ and $32^{\circ} \mathrm{S}$ ) an easterly flux is driven by the South Atlantic anticyclone. It connects to the southern AEJ in particular during summer,

(d) south of $32^{\circ} \mathrm{S}$, a westerly moisture flux occupies most of the air column and migrates during the year, reaching its northernmost position from May to July.

\subsection{Moisture fluxes variability along the west coast of southern Africa}

The stability of a time series is essential in a multivariate analysis approach. A non-parametric statistical method (Mann-Whitney-Pettitt test) was applied to computed zonal moisture fluxes and showed major breaks in stationarity. To overcome these instabilities, we extracted and only considered the high frequency filtered zonal moisture fluxes using a high-pass Butterworth filter at 96 months. Consequently, we focus here on time scales of variability below 8 years.

EOF techniques were applied to the highfiltered (HF) zonal moisture fluxes along the west coast of southern Africa using the covariance matrix : the spatial patterns of the firsts four EOFs are shown in Figure 3. The truncated basis defined by these four primary modes interestingly contributes almost half of the total variance explained.

The first mode is typical of the migration in latitude of the circulation linked with the midlatitude westerlies and South Atlantic anticyclone. It explains about $24.8 \%$ of the total variance. Loadings are particularly strong from the surface up to $600 \mathrm{mb}$ and are balanced in the subtropics at upper tropospheric levels. 

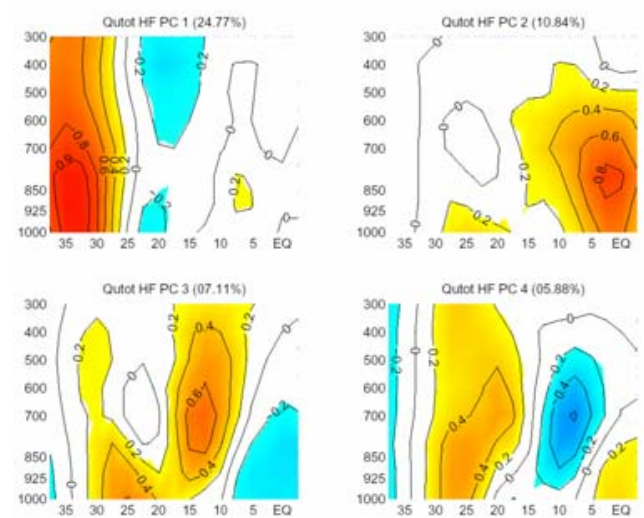

Figure 3 : Leading EOF modes of variability in highfrequency zonal moisture fluxes along the west coast of southern Africa.

The second mode characterizes the monsoon-like westerly moisture flux in the tropics, from the equator to about $15^{\circ} \mathrm{S}$. It represents $10.9 \%$ of the total variance explained. It has a simultaneous loading at the surface between $20^{\circ} \mathrm{S}$ and $30^{\circ} \mathrm{S}$. This mode is of particular importance in terms of water vapour input from the tropical Atlantic over the subcontinent. In the following we will refer to this component as the Equatorial Westerly mode. The global wavelet power spectrum for the Equatorial Westerly mode expansion coefficient reveals variability mostly at intra-annual time scales, with high-frequency background seasonal signals.

The two last modes are less clear to interpret but they show loadings at heights where the southern extension of the AEJ migrates throughout the year. These modes respectively explain about $7.1 \%$ and $5.9 \%$ of the total variance.

\section{RESULTS \& DICUSSIONS}

Figure 4 presents the January-February timeseries for the corresponding Equatorial Westerly mode expansion coefficient. A threshold at 0.6 of normalized anomalies deviation from the mean defines significant extreme years.

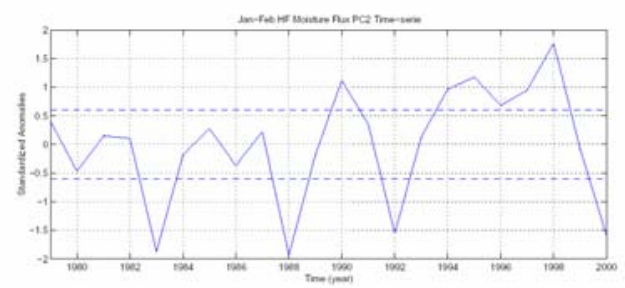

Figure 4 : January-February PC2 mode expansion coefficient for high frequency zonal moisture fluxes along the west coast of southern Africa from 1979 to 2000. Dashed lines indicate $+/-0.6$ level.
We choose respectively (1990, 1995 and 1998) and (1983, 1988, and 1992) as positive/negative events, for which the expression of the Equatorial Westerly mode in zonal fluxes appeared to be significantly enhanced/reduced. Interestingly, all but one year corresponds to the mature phase of ENSO. This could explain the absence of correlation between ENSO and rainfall in central southern Africa (Camberlin and Poccard, 2001).

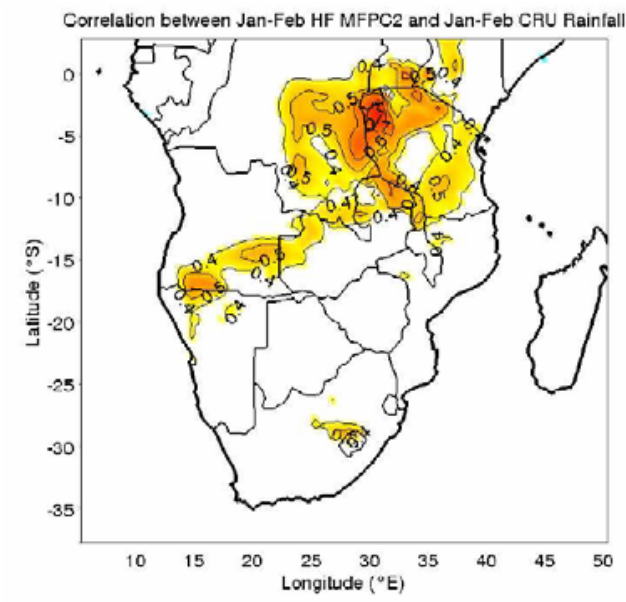

Figure 5 : Heterogeneous correlation between $\mathrm{HF}$ zonal moisture flux PC2 and CRU TS 2.0 rainfall in JanuaryFebruary over the period 1979-2000.

Heterogeneous correlation between JanuaryFebruary Equatorial Westerly mode expansion coefficient and CRU TS 2.0 rainfall are presented in Figure 5. High scores for synchronous correlation are found all around the Congo basin, with maximums from east/southeast DRC and northwest Tanzania stretching to the south along the Rift valley and westwards to south Angola. Rainfall composites (not shown) for positive (1990, 1995 and 1998) and negative (1983, 1988, and 1992) years of the January-February moisture flux PC2 time-series (Figure 4) confirm the symmetry of the relation with significant anomalies over these areas of maximum correlation scores. In conclusion, the modulation in intensity of the monsoon-like westerly flux at tropical latitudes of southern Africa west coast during mid-summer months (January-February) appears to directly impact rainfall amounts all around the eastern/southeastern Congo basin extending as far as $15^{\circ} \mathrm{S}$. This agrees with the findings of Mapande and Reason (2005) suggesting links between enhanced westerly moisture input from the Congo basin and above normal rainfall to the east. 
We used also composite analyses on vertical velocity, zonal moisture fluxes (not shown) and convergence (Figure 6) to give further elements of description regarding the underlying mechanisms.
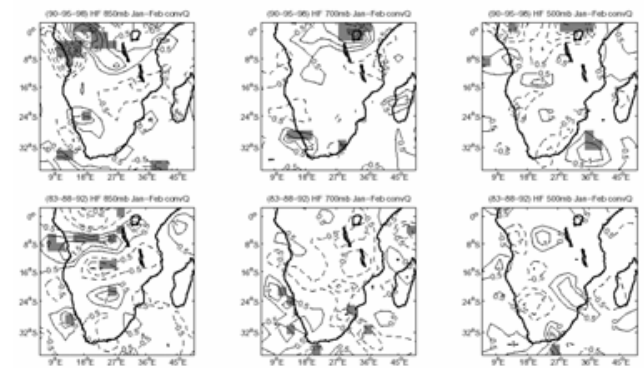

Figure 6 : (1990, 1995, and 1998) composite (top) and (1983, 1988, and 1992) composite (bottom) for HF humidity convergence computed from NCEP R2 at both $850 \mathrm{mb}$ (left), $700 \mathrm{mb}$ (middle) and $500 \mathrm{mb}$ levels (right) in January-February over the period [1979-2000] with shaded areas representing $95 \%$ confidence level of Student t-test.

For years when the Equatorial Westerly mode was particularly enhanced, anomalous advection of moisture over the Congo basin creates a situation where deep convection processes are enhanced. Excess water vapour is channeled from these regions around the Congo basin to the east and southeast at surface, while the southern extension of the AEJ appears to be the mechanism for transporting more moisture southwards at midtropospheric levels. Anomalies in vertical velocities further support an enhanced water vapour transfer to the south, resulting in more moisture available for local convection and enhanced rainfall over the uplands surrounding the Congo basin.

During the years when the equatorial westerly monsoon-like moisture transport was reduced, a deficit in moisture advection over the Congo basin was noticeable. In addition, a weaker Walker type circulation occurred, suggesting a shift of its ascending branch eastwards to the southwest Indian ocean and southeastern parts of southern Africa. This led to reduction in convection and below average rainfall. This finding agrees with D'Abreton and Tyson (1995) who showed that during dry summers, transport from the tropical Atlantic is replaced by an enhanced moisture source over the Indian ocean.

In this work, we tried to describe the role of the tropical Atlantic exclusively through zonal moisture input. However the meridional moisture transport across the south Atlantic onto southern Africa has to be further addressed. Moreover this study did not consider controls exerted by Indian ocean regions and this should be examined further. The modulation of other isolated atmospheric features needs deeper investigation, as for the migration of the south Atlantic anticyclonic cell. The variability in the southern dependence of the African Easterly Jet also requires to be better documented. However, our study shows that a better understanding of processes linked with moisture input from the tropical south Atlantic could help to assess issues such as summer rainfall predictability over tropical areas of southern Africa.

\section{AKNOWLEDGEMENTS}

We would like to acknowledge the financial support of the South African Water Research Commission and the French CNRS /South African NRF cooperative project. We are grateful to Chris Reason for his help. Nicolas Vigaud thanks the personal of the Centre de Recherches de Climatologie at University of Bourgogne, France for its hospitality. NCEP-DOE AMIP II Re-analyses are provided by the NOAA-CIRES, Climate Diagnostic Center, Boulder, Colorado (available online at http://www.cpc.ncep.noaa.gov/), CRU rainfall were obtained from $\mathrm{CRU}$.

\section{REFERENCES}

Camberlin, S. J., P., and I. Poccard (2001), Seasonality and atmospheric dynamics of the teleconnection between African rainfall and tropical sea-surface temperature : Atlantic vs. enso, Int. J. Climatol., 21, 973-1005.

Chen, T. (1985), Global water vapor flux and maintenance during fgge, Mon. Wea. Rev., 113, 1801-1819.

Cook, C., C. J. C. Reason, and B. Hewitson (2004), Wet and dry spells within particularly wet and dry summers in the south African summer rainfall region, Clim. Res., 26(17-31).

D'Abreton, P., and J. Lindesay (1993), Water vapour transport over southern Africa during wet and dry early and late summer months, Int. J. Climatol., 13(151-170).

D'Abreton, P., and P. Tyson (1995), Divergent and non-divergent water vapour transport over southern Africa during wet and dry conditions, Met. Atmos. Phys., 55(47-59).

Fauchereau, N. (2004), Transport, Bilan et Cycle de l'Eau Atmospheric en Afrique Australe : Mise en Relation avec la Variabilite de la Temperature de Surface de Mer dans l'Hemisphere Sud, These de Doctorat, Centre de Recherches Climatiques, Universite de Bourgogne. 
Hastenrath, S. (1985), Climate Circulation in the Tropics, 455 pp., D. Reidel Publishing Company.

Hastenrath, S., and A. C. Hirst (1983), Atmosphere-ocean mechanisms of climate anomalies in the Angola-tropical Atlantic sector, J. Phys. Oceano.

Kanamitsu, M., W. Ebisuzaki, J. Woollen, S.-K. Yang, J. Hnilo, M. Fiorino, and G. L. Potter (2002), Ncep-doe amip-2 reanalysis (r-2), Bul. of the Atmos. Met. Soc., Nov., 1631-1643.

Mapande, A. T., and C. Reason (2005), Interannual rainfall variability over western Tanzania, Int. J. Climatol., 25, 1355-1368.

Mitchell, T. D., T. R. Carter, P. D. Jones, M. Hulme, and M. New (2004), A comprehensive set of high-resolution grids of monthly climate for Europe and the globe: the observed record (1901-2000) and 16 scenarios (2001- 2100), Tyndall Centre Working Paper, 55.

Mulenga, H. M. (1998), Southern African Climatic Anomalies, Summer Rainfall and the Angola Low, University of Cape Town.

Nicholson, S. E. (2000), The nature of rainfall variability over Africa on time scales of decades to millennia, Global Plan. Change, 26, 137-158.

Nicholson, S. E., and D. Entekhabi (1987), The nature of rainfall variability in equatorial and southern Africa : Relationships with SSTs along the southwestern coast of Africa, J. of Clim. And Applied Meteorol., 26, 561-578.

Nicholson, S. E., and J. P. Grist (2003), The seasonal evolution of the atmospheric circulation over west Africa and equatorial Africa, J. of Climate, 16.

Peixoto, J., and A. Oort (Eds.) (1992), Physics of Southern African Climate, 520 pp., SpringerVerlag.

Preston-Whyte, R., and P. Tyson (1988), The Atmosphere and Weather of Southern Africa, 334 pp., Oxford Univ. Press, Cape Town.

Reason, C. J. C., and D. Jagadheesha (2005), A model investigation of recent enso impacts over southern Africa, Meteorol. Atmos. Phys., 89, 181-205.

Rocha, A., and I. Simmonds (1997), Interannual variability of southeastern African summer rainfall part 1: Relationships with air-sea interaction processes, Int. J. Climatol., 17, 235-265.

Rouault, M., P. Florenchie, N. Fauchereau, and C. J. C. Reason (2003), South east tropical Atlantic warm events and southern African rainfall, Geophys. Res. Lett., 30(5), 8009, doi: 10.1029/2002GLO14840.

Schott, F., J. Carton, W. Hazeleger, W. Johns, Y. Kushnir, C. Reason, and S. P. Xie (2003), White paper on a tropical Atlantic climate experiment (t.a.c.e.), CLIVAR Atlantic Implementation Panel. 